\title{
FILOZOFICZNE ASPEKTY KONSTYTUOWANIA SIĘ APARATU POJĘCIOWEGO CHEMII
}

\begin{abstract}
Streszczenie. Wśród filozofów nauki panuje rozpowszechnione przekonanie, że spór o realizm nie wpływa w sposób istotny na praktykę badawczą nauk przyrodniczych, a postawa realistyczna jest naturalnym stanowiskiem epistemologicznym przyjmowanym przez przyrodników. W artykule podana jest argumentacja na rzecz tezy, że w naukach przyrodniczych są formułowane koncepcje teoretyczne, które wywołują wśród uczonych istotne kontrowersje poznawcze, które nie pozostają bez wpływu na ich praktykę badawczą. Rozważona zostanie teza Gastona Bachelarda, że przezwyciężenie przez daną dziedzinę nauki realistycznego 'obciążenia' jej aparatu konceptualnego ma istotny wpływ na jej rozwój. Prowadzone rozważania będą opierały się na analizie przykładów wziętych z praktyki badawczej chemii XIX i początku XX wieku, w której dyskutowano problem statusu poznawczego przekonań, dotyczących istnienia odniesień przedmiotowych takich pojęć, jak: atom (atom chemiczny), wzór strukturalny (formuła racjonalna) czy wiązanie chemiczne.
\end{abstract}

Słowa kluczowe: spór o realizm, Gaston Bachelard, aparat konceptualny, atom chemiczny, wzór strukturalny, wiązanie chemiczne

1. Wstęp. 2. Wpływ postaw epistemologicznych uczonych na rozwój praktyki badawczej nauk przyrodniczych w ujęciu Gastona Bachelarda. 3. Analiza ewolucji wybranych pojęć nowożytnej i współczesnej chemii w kontekście konstytuowania się ich profili epistemologicznych.

3.1. Proces kształtowania się stanowiska racjonalizmu naukowego w odniesieniu do atomów chemicznych. 3.2. Konstytuowanie się racjonalnego podejścia do wzorów strukturalnych (formuł racjonalnych) jako reprezentacji struktur cząsteczek w kontekście sporów o ich poznawczą interpretację. 3.3. Spór o status poznawczy teorii wiązań chemicznych. 4. Zakończenie.

\section{WSTĘP}

Jedna z centralnych kontrowersji współczesnej filozofii nauki dotyczy poznawczej i ontologicznej interpretacji wytworów badań naukowych. Sformułowano cały wachlarz stanowisk od skrajnego realizmu metafizycznego i teoriopoznawczego po instrumentalizm związany 
z antymetafizycznie zorientowanym pozytywizmem i neopozytywizmem. Na rzecz tych stanowisk i kontra nim podano bardzo wiele argumentów. Jednakże wśród filozofów nauki dominowało i dominuje przekonanie, że kontrowersja ta nie jest istotna dla praktyki badawczej nauk przyrodniczych, gdyż nie wpływa ani na sposób uprawiania badań naukowych, ani na uzyskiwane w tych badaniach rezultaty. Zdecydowana większość filozofów nauki uważa, że przyrodoznawcy, zwłaszcza eksperymentatorzy, są przekonani zarówno o prawdziwości praw i teorii naukowych, jak i co do istnienia przedmiotów teoretycznych przez nie postulowanych. Niekiedy podaje się uzasadnienie dla takiej opinii, twierdząc, że przyjmowanie przez uczonych postawy realistycznej sprzyja rozwojowi nauki ${ }^{1}$ i ma wpływ na efektywność laboratoryjnej praktyki badawczej².

Gaston Bachelard był jednym z nielicznych filozofów nauki, którzy uważali, że przezwyciężenie przez daną dziedzinę nauki realistycznego 'obciążenia' jej aparatu konceptualnego ma istotny wpływ na jej rozwój. Prowadząc badania historyczne nad dziejami niektórych nauk przyrodniczych, zauważył, iż uczeni, tworzący aparat pojęciowy tych nauk, bardzo często zajmowali względem niego przeciwstawne stanowiska epistemologiczne. Twierdził, że dialektyczne napięcie, jakie występuje między postawami epistemologicznymi uczonych, ma kluczowe znaczenie dla kształtowania się tego aparatu, a tym samym nie pozostaje bez wpływu na praktykę badawczą nauk przyrodniczych.

W artykule przeanalizuję wpływ postaw epistemologicznych chemików na kształtowanie się aparatu pojęciowego nowożytnej

1 Twierdził tak np. Paul Feyerabend, który uważał, że choć realistyczna interpretacja wielu konstrukcji teoretycznych napotyka na poważne trudności, to jest ona efektywna z punktu widzenia rozwoju badań naukowych. Zob. P. Feyerabend, Realizm i instrumentalizm. Uwagi o logice potwierdzania przez fakty, w: tenże, Jak być dobrym empirysta, tłum. z ang. K. Zamiara, Warszawa 1979, 152-193.

2 Argumentowałem na rzecz tej tezy w książce: P. Zeidler, Chemia w świetle filozofii. Studia z filozofii, metodologii i semiotyki chemii, Poznań 2011, 103-107, 109-118 oraz 132-135. 
i współczesnej chemii, które miało miejsce w dziewiętnastym wieku i w pierwszej połowie wieku dwudziestego ${ }^{3}$. Za punkt wyjścia dalszych rozważań przyjmę następujące sformułowanie sporu o realizm na poziomie epistemologicznym: Czy możemy (przynajmniej w zasadzie) posiadać uzasadnione przekonania dotyczące istnienia przedmiotów teoretycznych postulowanych przez nasze koncepcje teoretyczne? ${ }^{4}$ Użycie terminu 'koncepcja', zamiast na ogół używanego w tym kontekście terminu 'teoria', jest uzasadnione tym, że rozwój chemii nie był wyznaczony przez teorie fundamentalne - jak to miało miejsce w fizyce - lecz opierał się na tworzeniu koncepcji teoretycznych o ograniczonym zakresie stosowalności i w ścisłym związku z próbami rozwiązywania problemów, jakie pojawiały się w praktyce eksperymentalnej chemii ${ }^{5}$. Dokonam skrótowej analizy sporów o status poznawczy przekonań dotyczących istnienia odniesień przedmiotowych trzech pojęć, które odegrały kluczową rolę w ukonstytuowaniu się chemii jako nowożytnej nauki przyrodniczej: atomu (atomu chemicznego), wzoru strukturalnego (formuły racjonalnej) oraz wiązania chemicznego. Wykażę, że postawy

3 Historyczny rozwój pojęć chemicznych poddał szczegółowej analizie Roman Mierzecki, lecz ukazanie wpływu postaw filozoficznych chemików na ten proces nie było celem jego monografii. Zob. R. Mierzecki, Historyczny rozwój pojęć chemicznych, Warszawa 1985.

4 Epistemologicznemu sformułowaniu sporu o realizm nadaje się na ogół postać bardziej ogólną: Czy możemy (przynajmniej w zasadzie) posiadać uzasadnione przekonania na temat prawdziwości lub fałszywości naszych teorii oraz istnienia przedmiotów teoretycznych? Ze względu na podstawowy cel mojego artykułu ograniczam swoje rozważania do analizy stanowisk epistemologicznych, odnoszących się do przekonań dotyczących kwestii istnienia przedmiotów teoretycznych.

5 W filozofii chemii powyższa teza jest dość często kwestionowana. Wskazuje się na przykład na prawo układu okresowego pierwiastków Mendelejewa lub teorię atomistyczną Daltona jako koncepcje o wysokim stopniu ogólności, lecz należy zauważyć, że mają one zasadniczo charakter jakościowy, choć umożliwiają także ilościową charakterystykę atomów oraz cząsteczek tworzących substancje chemiczne. Ze względu na tradycję posługiwania się terminem teoria w odniesieniu do bardzo zróżnicowanych metodologicznie wytworów pracy badawczej chemików będę w dalszych rozważaniach posługiwał się zamiennie terminami teoria i koncepcja. 
epistemologiczne chemików - często ze sobą niezgodne - nie pozostawały bez wplywu na proces formowania się konceptualnych ram teoretycznych nowożytnej i współczesnej chemii, a tym samym były jednym z czynników, które determinowały jej praktykę badawczą ${ }^{6}$.

\section{WPŁYW POSTAW EPISTEMOLOGICZNYCH UCZONYCH NA ROZWÓJ PRAKTYKI BADAWCZEJ NAUK PRZYRODNICZYCH W UJĘCIU GASTONA BACHELARDA}

Gaston Bachelard należał do tych niewielu dwudziestowiecznych filozofów nauki, którzy analizowali wpływ różnych koncepcji filozoficznych na rozwój aparatu konceptualnego nauk przyrodniczych ${ }^{7}$. Jego zdaniem ewolucja pojęć nauk przyrodniczych wiąże się ściśle z kontrowersją tworzącą się wokół opozycji realizm - racjonalizm. Uczeni muszą pokonywać przeszkody epistemologiczne, aby dana dyscyplina nauki mogła osiągnąć poziom teoretycznej dojrzałości. Podstawową przeszkodą w uprawianiu nauki jest substancjalizm związany z naiwnym realizmem. Znajomość dziejów nauk przyrodniczych skłoniła autora Filozofi, która mówi nie. Esej o filozofii nowego ducha w nauce do zadania pytania: „Czy naprawdę sądzicie, że naukowiec jest realistą we wszystkim, co myśli? Czy jest realistą, kiedy czyni założenia, czy jest realistą kiedy streszcza, czy jest realistą, kiedy tworzy schematy, czy jest realistą kiedy się myli? Czy na

6 Powyższa teza może być uzasadniona w oparciu o szczegółowe badania nad dziejami chemii, co wymagałoby napisania obszernej monografii z zakresu historii nauki. Ze względu na ograniczone ramy tego artykułu ograniczę się do szkicowego przedstawienia epistemologicznych kontrowersji, jakie towarzyszyły kształtowaniu się wybranych pojęć należących do aparatu pojęciowego nowożytnej i współczesnej chemii.

7 W polskiej literaturze przedmiotu poglądy Bachelarda na naukę omawiał szczegółowo Damian Leszczyński w: D. Leszczyński, Ciągłość i zerwanie w historii wiedzy, Warszawa 2008 oraz D. Leszczyński, K. Szlachcic, Wprowadzenie do francuskiej filozofii nauki. Od Comte'a do Foucaulta, Wrocław 2003. 
pewno jest realistą, kiedy twierdzi?"”. Odpowiadając na to pytanie, odwołał się do psychologii umysłu naukowego, którą utożsamiał z psychoanalizą. Miała ona za zadanie wyznaczyć profile epistemologiczne pojęć naukowych poszczególnych badaczy ${ }^{9}$ Na profil epistemologiczny pojęcia naukowego składają się: naiwny realizm, pozytywistyczny empiryzm, klasyczny racjonalizm, pełny racjonalizm i wreszcie racjonalizm stosowany (dyskursywny). Filozoficzna analiza widmowa określa wpływ różnych filozofii na poznanie naukowe, dokonujące się za pomocą centralnych pojęć danej dyscypliny wiedzy. W porządku genetycznym wiedza wyrażana za pomocą pojęć naukowych ewoluuje od realizmu (naiwnego) do empiryzmu, a następnie do racjonalizmu. Wcześniejszy etap w procesie ewoluowania pojęć stanowi przeszkodę, którą trzeba przezwyciężyć, aby osiągnąć etap następny. Poszczególni uczeni z każdym pojęciem mogą wiązać inne filozoficzne widmo spektralne, co ujawnia pluralizm epistemologicznych postaw uczonych, lecz cały aparat pojęciowy nauki nowożytnej zmierza w kierunku racjonalizmu. Zwieńczeniem procesu ewolucji pojęć jest racjonalizm stosowany (dyskursywny), zgodnie z którym rozwój nauki jest efektem ciągłego dialektycznego napięcia, jakie występuje między substancjalistyczną ze swej natury praktyką materialną nauki, a racjonalizującą tę praktykę refleksją teoretyczną.

Bachelard nie łączył bezpośrednio stanowiska racjonalizmu $\mathrm{z}$ jakąś konkretną postacią realizmu naukowego lub antyrealizmu. Najwyższa forma racjonalizmu - racjonalizm stosowany (dyskursywny) wyraża się, jego zdaniem, w ciągłej gotowości uczonych

8 G. Bachelard, Filozofia, która mówi nie. Esej o filozofii nowego ducha w nauce, tłum. z fr. J. Budzyk, Gdańsk 2000, 44.

9 W niektórych kontekstach Bachelard posługuje się zamiennie terminami 'profil epistemologiczny pojęcia naukowego' i 'przeszkoda epistemologiczna'. Różnica między tymi pojęciami polega na tym, że genetycznie wcześniejsze składniki profilu filozoficznego pojęcia stanowiły przeszkody epistemologiczne dla składników późniejszych. Bachelard pisze: „Obydwa pojęcia - przeszkody epistemologicznej i profilu epistemologicznego mógłbym połączyć, ponieważ profil epistemologiczny zachowuje ślady przeszkód, które musiała przezwyciężyć kultura"; tamże, 53. 
do zaprzeczania swoim poglądom na temat stosunku tworzonych przez nich konstrukcji pojęciowych do obiektywnej rzeczywistości. Bachelard mówił w tym kontekście o różnych współczynnikach rzeczywistości, choć bliżej nie objaśniał tego pojęcia. Jako zdeklarowany zwolennik poglądu, że wszelka wiedza naukowa nie jest odkrywana przez badaczy, lecz jest przez nich konstruowana, uznawał spory o status poznawczy teoretycznych wytworów badań naukowych za podstawowy czynnik wpływający na rozwój aparatu pojęciowego nauki.

\section{ANALIZA EWOLUCJI WYBRANYCH POJĘĆ NOWOŻYTNEJ I WSPÓŁCZESNEJ CHEMII W KONTEKŚCIE KONSTYTUOWANIA SIĘ ICH PROFILI EPISTEMOLOGICZNYCH}

Do kluczowych pojęć teoretycznych nowożytnej i współczesnej chemii należy zaliczyć, między innymi, pojęcia: 'atomu' ('atomu chemicznego'), 'wzoru strukturalnego' ('formuły racjonalnej') oraz 'wiązania chemicznego'. Konstytuowanie się tych pojęć i ich rola w praktyce teoretyczno-eksperymentalnej nowożytnej i współczesnej chemii była ściśle związana $z$ ich profilami epistemologicznymi, które kształtowały się w dyskursie chemików w XIX wieku i na początku wieku XX. Proces ten doprowadził do pokonania przeszkody substancjalistycznej związanej z dominującą w alchemii i chemii XVII i XVIII wieku praktyką eksperymentalną ${ }^{10}$. W chemii XIX wieku konkurowały ze sobą dwa podejścia do jej przedmiotu: substancjalistyczne i ewentystyczne. W ujęciu substancjalistycznym chemia to nauka o substancjach - ich składzie, strukturze, własnościach i reaktywności. Natomiast w ujęciu ewentystycznym

10 Zagadnienie przezwyciężania w chemii przeszkody substancjalistycznej analizowałem szczegółowo w P. Zeidler, O pokonywaniu przeszkody substancjalistycznej w chemii w świetle stanowiska racjonalizmu stosowanego Gastona Bachelarda, w: Granice nauki, red. Z. Pietrzak, Lectiones \& Acroases Philosophicae 6(2013)1, 33-57. 
chemia to - w pierwszym rzędzie - nauka o reaktywności substan$c j^{11}{ }^{11}$. We współczesnej chemii rozróżnienie to straciło na znaczeniu, lecz w XIX wieku determinowało sposób rozumienia wielu jej kluczowych pojęć. $Z$ substancjalistycznym podejściem do przedmiotu chemii wiązano zazwyczaj stanowisko realistyczne, gdy podejściu ewentystycznemu towarzyszyło instrumentalistyczne traktowanie tworzonych konstrukcji pojęciowych. Realistyczna versus instrumentalistyczna ich interpretacja prowadziła do ukonstytuowania się dwóch programów badawczych chemii, które w odmienny sposób wyjaśniały eksperymentalnie stwierdzane właściwości substancji chemicznych. Walther Nernst zaproponował podział tych ostatnich na trzy klasy: właściwości molowe, addytywne i konstytutywne. „Właściwości molowe to takie, które nie zależą od konstytucji molekuł a jedynie od ich ilości (np. ciśnienie i objętość gazu w warunkach, w których można zaniedbać oddziaływania międzycząsteczkowe, 'ruchy Browna' małych cząstek); właściwości addytywne, które zależą od właściwości poszczególnych składników substancji chemicznych (np. atomów, jonów, rodników), lecz nie od ich wewnętrznej struktury (np. ciężar molekularny, współczynnik refrakcji, szybkość dyfuzji); właściwości konstytutywne, które zależą zarówno od właściwości składników cząsteczek substancji chemicznych, jak i od ich wewnętrznej struktury, a więc nie mogą być rozpatrywane wyłącznie jako suma ich właściwości (np. aktywność optyczna, zdolność do wchodzenia $\mathrm{w}$ reakcje $\mathrm{z}$ innymi substancjami, charakterystyka widm absorpcyjnych)"12. Wyjaśnianie właściwości molowych

11 Na ontologiczną różnicę w podejściu do przedmiotu chemii w kontekście rozważań nad mechanicyzmem w chemii zwrócił uwagę Adam Synowiecki w: Tendencje mechanistyczne w rozwoju chemii nowożytnej w: Z dziejów mechanicyzmu w fizyce i chemii, red. W. Krajewski, Wrocław 1974, 107. Wyróżnił on 'ontologię somatyzmu' - substancjalistyczną i 'ontologię ewentystyczną', która ujmuje przedmiot badany jako strukturę złożoną z procesów i zdarzeń.

12 Powyższa charakterystyka trzech typów właściwości substancji chemicznych, która wywodzi się od Nernsta, została sformułowana przez Davida Bantza w: The Structure of 
i addytywnych substancji chemicznych zależy od takich pojęć teoretycznych, jak: cząsteczka, atom (atom chemiczny), jon, rodnik i kilku innych, a wyjaśnianie właściwości konstytutywnych wymaga wprowadzenia, między innymi, takich pojęć jak: struktura cząsteczek substancji chemicznych i wiązanie chemiczne. Ponieważ to przede wszystkim właściwości konstytutywne są specyficznie chemiczne, dlatego ich wyjaśnienie stanowiło podstawowe zadanie zarówno substancjalistycznego, jak i ewentystycznego programu badawczego chemii XIX i początku XX wieku. Zwłaszcza dla rozwoju tego drugiego programu badawczego istotne były pojęcia, które będą analizowane w kolejnych paragrafach tej części artykułu: 'atomu' ('atomu chemicznego'), 'wzoru strukturalnego' ('formuły racjonalnej') jako reprezentacji struktury cząsteczki związku chemicznego i 'wiązania chemicznego'. We współczesnej chemii, w której dominuje - zgodnie $\mathrm{z}$ terminologią Bachelarda - stanowisko racjonalizmu stosowanego, opozycja między realistyczną a instrumentalistyczną interpretacją wymienionych konstrukcji pojęciowych straciła na znaczeniu. Zajmowanie określonej postawy epistemologicznej względem nich zależy, w dużym stopniu, od kontekstu teoretyczno-eksperymentalnego, w którym chemicy posługują się tymi pojęciami ${ }^{13}$.

\subsection{PROCES KSZTAŁTOWANIA SIĘ STANOWISKA RACJONALIZMU NAUKOWEGO W ODNIESIENIU DO ATOMÓW CHEMICZNYCH}

„W XIX wieku występowały dwa typy teorii atomistycznej: powszechnie akceptowana (zwykle tylko implicite) teoria chemicznego atomizmu, stanowiąca rozumową podstawę wyznaczania względnych ciężarów atomów i wzorów cząsteczkowych; i silnie kontrowersyjna

Discovery: Evolution of Structural Accounts of Chemical Bonding, w: Scientific Discovery: Case Studies, red. T. Nickles, Dordrecht 1980, 306-307.

13 Zob. B. Bensaude-Vincent, Chemistry Beyond the 'Positivism vs Realism' Debate, w: Stuff. The Nature of Chemical Substances, red. K. Ruthenberg, J. van Brakel, Würzburg 2008, 45-53. 
teoria fizycznego atomizmu, formułująca twierdzenia dotyczące podstawowej struktury wszystkich substancji” ${ }^{14}$. Pierwsza $z$ tych teorii, związana ściśle $\mathrm{z}$ rozwojem dziewiętnastowiecznej chemii, została zapoczątkowana przez Daltona, który ujmował przemiany chemiczne jako przegrupowania atomów, lecz centralne znaczenie dla upowszechnienia się jego teorii łączyło się z możliwością wyznaczania względnych ciężarów atomowych, co z kolei umożliwiało wyjaśnienie prawa stałości składu. Dalton był skłony uznawać atomy za realnie istniejące byty, lecz tylko wtedy, gdy rozpatruje się je jako najmniejsze cząstki, z których zbudowane są molekuły stanowiące podstawowy przedmiot zainteresowania chemii. Natomiast nie interesowały go atomy, rozpatrywane $\mathrm{z}$ fizykalnego punktu widzenia, jako najmniejsze elementy, z których zbudowana jest materia. Można zatem zgodzić się $z$ tezą, że od Daltona rozpoczyna się proces odróżniania dwóch typów atomizmu: fizycznego i chemicznego ${ }^{15}$.

$\mathrm{W}$ pierwszej połowie dziewiętnastego wieku powstało $\mathrm{w}$ chemii organicznej kilka teorii, które próbowały wyjaśnić reaktywność substancji chemicznych składem i konstytucją ich cząsteczek: teoria rodników J.B. Dumasa, teoria jąder A. Laurenta i teoria unitarna $\mathrm{Ch}$. Gerhardta ${ }^{16}$. Autorzy tych koncepcji zaproponowali różne sposoby reprezentacji składu i budowy cząsteczek substancji chemicznych, lecz odeszli od ich realistycznej interpretacji. Gerhardt przyjmował, że skład i budowa cząsteczek danej substancji mogą być reprezentowane przez różne 'formuły racjonalne', które jednakże nie oddają rzeczywistej budowy cząsteczek. Można powiedzieć, że w pierwszej połowie dziewiętnastego wieku większość chemików wiązała z pojęciem 'atomu chemicznego' pozytywistyczny profil epistemologiczny. Przełamanie instrumentalistycznej interpretacji koncepcji

14 W.H. Brock, Historia chemii, Warszawa 1999, 119.

15 Zob. B. Bensaude-Vincent, J. Simon, Chemistry the Impure Science, London 2008, 185-200.

16 Zob. R. Mierzecki, Historyczny rozwój pojęć chemicznych, Warszawa 1985, 151-164. 
atomistycznej nastąpiło dopiero na początku drugiej połowy dziewiętnastego wieku. Znamienna pod tym względem była wypowiedź Kekulégo: „Pytanie, czy atomy istnieją czy nie (atomy jako byty postulowane przez fizykę - P.Z.), ma z chemicznego punktu widzenia jedynie niewielkie znaczenie - jego roztrząsanie należy raczej do metafizyki. W chemii natomiast mamy tylko zbadać, czy pojęcie atomów jest hipotezą stosowną do wyjaśniania zjawisk chemicznych [...]. Nie waham się powiedzieć, że z filozoficznego punktu widzenia nie wierzę w rzeczywiste istnienie atomów jako w ścisłym znaczeniu niepodzielnych części materii. Spodziewam się raczej, że dla tego, co dzisiaj nazywamy atomami, znalezione zostanie kiedyś wyjaśnienie matematyczno-mechaniczne, które udzieli nam informacji o ciężarze atomowym, wartościowości i o innych właściwościach tzw. atomów. Jednakże jako chemik uważam uznanie istnienia atomów nie tylko za wskazane, lecz nawet za konieczne. Idę jeszcze dalej i twierdzę, że chemiczne atomy istnieją, jeśli rozumieć przez nie te części materii, które w reakcjach chemicznych nie podlegają dalszemu podziałowi" ${ }^{\prime 7}$. Można zatem stwierdzić, że profil epistemologiczny, który Kekulé przypisywał pojęciu 'atom', zależał od dziedziny nauki, w której było ono używane: w fizyce - instrumentalistyczny, a w chemii - realistyczny. Realistyczne ujęcie atomów chemicznych wynikało z eksplanacyjnej i predyktywnej funkcji, jaką pełniły one w chemii. W latach sześćdziesiątych i siedemdziesiątych dziewiętnastego wieku ugruntowało się ono wraz ze stworzeniem podstaw stereochemii przez Jacobusa van't Hoffa i Josepha Le Bela. Dostarczyła ona mocnych argumentów na rzecz tezy, że właściwości substancji zależą od przestrzennego rozmieszczenia atomów w cząsteczkach. Niewątpliwie, rozwój chemii strukturalnej oraz opracowanie metod reprezentacji struktury cząsteczek za pomocą wzorów strukturalnych miały wpływ na to, że teoria atomistyczna, począwszy od lat sześćdziesiątych XIX wieku, zaczęła być traktowana realistycznie przez

17 Cyt. za A. Synowiecki, art. cyt. 114. 
zdecydowaną większość chemików, podczas gdy fizycy uznawali ją, aż do końca tego wieku, za spekulację czysto teoretyczną.

Jednakże atomizm chemiczny drugiej połowy XIX wieku nie był stanowiskiem realizmu metafizycznego, którego charakterystyczną cechą jest esencjalizm. Chemicy nie rozpatrywali atomów w kontekście pytań dotyczących ostatecznych składników budowy materii, lecz w kontekście wyjaśniania różnych właściwości substancji chemicznych, a zwłaszcza ich reaktywności. Można zatem zgodzić się z opinią Adama Synowieckiego, że w podejściu dziewiętnastowiecznych chemików do problemu istnienia atomów można wyróżnić dwa stanowiska: fikcjonalistyczne, zgodnie z którym chemicy stosują hipotezę atomistyczną jedynie jako dogodne narzędzie analizowania zjawisk chemicznych, oraz quasi-realistyczną, ,zgodnie z którą atomy istnieją wprawdzie obiektywnie, ale to ich istnienie ogranicza się tylko do trwania w cząsteczkach i jest cząsteczkom podporządkowane" ${ }^{18}$.

Profil epistemologiczny pojęcia 'atom chemiczny' należy zatem podciągnąć pod stanowisko racjonalizmu stosowanego w rozumieniu Bachelarda, gdyż przyjęcie quasi-realistycznej interpretacja tej konstrukcji teoretycznej było konsekwencją funkcji, jaką pojęcie atomu pełniło w praktyce teoretycznej i eksperymentalnej chemii tego okresu. Ernst Cassirer uważał, że chemicy nie odnoszą atomów do zbioru obserwowalnych właściwości, lecz „'atomy' są pojęciami, które pośredniczą w utworzeniu globalnej sieci fenomenologicznych właściwości" ${ }^{19}$. Stanowisko jednoznacznie realistyczne w kwestii istnienia atomów przyjmował A. M. Butlerow, który twierdził, że atomy istnieją trwale niezależnie od natury złożonej z nich całości, lecz i on uważal, że właściwości atomów w cząsteczkach zależą od innych atomów wchodzących w ich skład ${ }^{20}$. Należy jednakże odnotować,

18 Tamże, 114

19 Zob. na temat poglądów Cassirera na 'atomy chemiczne': B. Bensaude-Vincent, J. Simon, dz. cyt., 192.

20 Zob. A. M. Butlerow, Teoria budowy związków organicznych, Warszawa 1953, 120. 
że przeciwnicy realistycznego ujmowania atomów w chemii istnieli jeszcze na początku XX wieku. Nawiązując do tradycji E. Macha i W. Ostwalda, starali się wyjaśniać reaktywność substancji chemicznych bez posługiwania się pojęciem 'atomu'. Filozofem i przyrodoznawcą, który również pozostawał sceptyczny wobec atomizmu chemicznego, był P. Duhem, który uważał, że można wyjaśnić właściwości chemiczne substancji bez odwoływania się do pojęcia atomu, a jedynie posługując się prawami termodynamiki. Stanowisko to zostanie przedstawione szerzej, gdy w trzecim paragrafie tego rozdziału omówię spory o status poznawczy pojęcia 'wiązania chemicznego'. Jednakże już teraz można stwierdzić, że rozpatrywanie centralnych kategorii pojęciowych chemii z perspektywy energetyzmu prowadziło w konsekwencji do redukcji chemii do fizyki, a tym samym znosiło świat bytów specyficznie chemicznych, bez których trudno sobie wyobrazić efektywną praktykę laboratoryjną chemii. Z punktu widzenia tej ostatniej przypisywanie 'atomom chemicznym' statusu realistycznego jest wyrazem stanowiska racjonalizmu stosowanego, gdyż w efektywny sposób wpływa na laboratoryjną praktykę badawczą chemików.

\subsection{KONSTYTUOWANIE SIĘ RACJONALNEGO PODEJŚCIA DO WZORÓW} STRUKTURALNYCH (FORMUŁ RACJONALNYCH) JAKO REPREZENTACJI STRUKTUR CZĄSTECZEK W KONTEKŚCIE SPORÓW O ICH POZNAWCZĄ INTERPRETACJĘ

W poprzednim paragrafie tego rozdziału wykazaliśmy, że na profil epistemologiczny pojęcia 'atom chemiczny' istotny wpływ miały sposoby reprezentacji struktury cząsteczek związków chemicznych, które za sprawą teorii J.B. Dumasa, A. Laurenta oraz Ch. Gerhardta pojawiły się w chemii w pierwszej połowie XIX wieku. Jednakże dopiero $\mathrm{w}$ drugiej połowie tego wieku ukształtowały się dwa odmienne sposoby podejścia do reprezentacji struktury chemicznej. Kekulé, który był zwolennikiem podejścia ewentystycznego do przedmiotu chemii, uważał, że wzory strukturalne (formuły racjonalne) reprezentuja 
zdolności substancji do wchodzenia w reakcje chemiczne. Natomiast Butlerow, który był zwolennikiem podejścia substancjalistycznego, ujmował wzory strukturalne (formuly racjonalne) jako reprezentacje aktualnej struktury cząsteczek substancji chemicznych ${ }^{21}$.

Zdaniem Kekulégo formuły racjonalne są reprezentacjami reaktywności substancji chemicznych, lecz nie są realistycznym przedstawieniem konstytucji cząsteczek tych substancji. Mają one na celu „dać przedstawienie chemicznej natury ciała, a mianowicie jego przemian i stosunków, według których odnosi się ono do innych ciał"22. Cząsteczkom, z których składają się niektóre substancje chemiczne, można przypisać kilka różnych formuł racjonalnych, które oddają ich reaktywność w zależności od zmieniających się warunków reakcji i reagentów biorących w nich udział. „Każda formuła, która wyraża jakieś przemiany substancji, jest racjonalna; $\mathrm{z}$ różnych formuł najracjonalniejsza jest ta, która wyraża równocześnie największą liczbę przemian" ${ }^{\prime 2}$. Natomiast w ujęciu Butlerowa formuła racjonalna przedstawia strukturę cząsteczek substancji chemicznej, która determinuje jej fizyczne, chemiczne i biologiczne właściwości. Określona formuła racjonalna reprezentuje strukturę cząsteczek tylko jednego związku chemicznego, co można uznać za praktyczny przejaw stosowania sztywnej teorii desygnacji ${ }^{24}$. Butlerow twierdzi1, że formuły racjonalne: „są chociaż jeszcze nie całkowicie, to przynajmniej do pewnego stopnia, prawdziwymi wzorami racjonalnymi. Każdemu ciału będzie można, w tym sensie, przypisać tylko jeden wzór racjonalny, a gdy staną się znane ogólne prawa zależności chemicznych właściwości ciał

21 W chemii XIX wieku posługiwano się zazwyczaj terminem 'formuła racjonalna' lub 'wzór racjonalny', który w XX wieku został zastąpiony terminem 'wzór strukturalny'. W dalszej części artykułu będę posługiwał się tym pierwszym terminem.

22 Cytat za A. Synowiecki, art. cyt. 117.

23 Cyt. za A. Synowiecki., art. cyt. 117-118

24 Zagadnienie zastosowania sztywnej (przyczynowej) teorii desygnacji w chemii omówiłem szczegółowo w artykule P. Zeidler, Semiotyczny i poznawczy status wzorów strukturalnych zwiq̨zków chemicznych a przyczynowa teoria oznaczania, w: P. Zeidler, Chemia w świetle filozofii, Poznań 2011, 137-151. 
od ich struktury chemicznej, wówczas podobny wzór będzie wyrażał wszystkie te właściwości”25. Można zatem stwierdzić, że w ujęciu Butlerowa profil epistemologiczny pojęcia 'formuła racjonalna' wiąże się z przyjęciem tezy, że jest to realistyczna reprezentacja ustalanej w badaniach eksperymentalnych struktury cząsteczek substancji chemicznej, która wyjaśnia i pozwala przewidywać jej właściwości. „Nie przypuszczam, aby ktokolwiek mógł zdecydować się na twierdzenie, że podczas gdy sama cząsteczka istnieje, 'budowa' jej jest czymś, co przechodzi, co nie istnieje w stanie teraźniejszym. A cóż to jest 'budowa' - w teraźniejszości - jeżeli nie pewien określony wzajemny stosunek atomów w cząsteczce"26.

W drugiej połowie XIX wieku podejście do struktury jako wyidealizowanej, lecz interpretowanej realistycznie, immanentnej właściwości cząsteczek stanowiło podstawę rozwoju teorii struktury chemicznej. Uległo ono wzmocnieniu wraz z rozwojem - wspomnianej już - stereochemii, która dostarczyła mocnych argumentów na rzecz tezy, że właściwości substancji zależą od przestrzennego rozmieszczenia atomów w cząsteczkach. Realistyczna interpretacja wzorów strukturalnych w istotny sposób determinowała praktykę eksperymentalną chemii laboratoryjnej, lecz napotkała na trudności związane $\mathrm{z}$ istnieniem struktur granicznych cząsteczek niektórych związków chemicznych.

Kekulé, zastanawiając się nad sposobem reprezentacji struktury cząsteczki benzenu w postaci sześciokąta foremnego, doszedł do wniosku, że jej strukturę należy oddać przez dwa równoważne wzory racjonalne, które różnią się usytuowaniem w pierścieniu wiązań podwójnych. Jednakże wzory te reprezentują „pozorną a nie rzeczywistą dwoistość struktur”. Cząsteczka, jego zdaniem, nie oscyluje pomiędzy stanami reprezentowanymi przez oba wzory, lecz jej rzeczywista struktura jest wypadkową struktur rezonansowych. Dla

25 Cyt. za R. Mierzecki, dz. cyt. 162.

26 A.M. Butlerow, dz. cyt. 120. 
cząsteczek zawierających wiązania zdelokalizowane (np. benzenu i jego pochodnych) funkcja falowa opisująca stan podstawowy danej cząsteczki jest tworzona jako kombinacja liniowa funkcji falowych opisujących poszczególne struktury graniczne. W klasycznej interpretacji teorii struktury chemicznej rezonans jest rozumiany jako średnia ważona struktur kanonicznych. Zgodnie z teorią rezonansu chemicznego Paulinga, która stanowiła istotne uzupełnienie jego teorii wiązań walencyjnych, strukturę rzeczywistej cząsteczki oddaje hybryda struktur rezonansowych. W tym ujęciu 'rezonans chemiczny' to pojęcie reprezentujące konstrukcję matematyczną, umożliwiającą uzyskanie w obliczeniach minimalnej energii stanu podstawowego cząsteczki, która zapewnia jej stabilność. Poszczególne wzory struktur kanonicznych, które reprezentują odpowiednio skonstruowane molekularne funkcje falowe, posiadają charakter fikcjonalny i nie reprezentują rzeczywistych struktur cząsteczki danego związku (np. benzenu).

Krytyka teorii rezonansu chemicznego miała dwa aspekty: ideologiczny - 'sprawa Czelincewa' i merytoryczny, który związany był z tym, że teoria rezonansu podważała realistyczną zasadę Butlerowa: jeden wzór strukturalny reprezentuje strukturę cząsteczek określonego związku chemicznego, która determinuje jego fizyczne, chemiczne i biologiczne właściwości ${ }^{27}$. Dlatego zwolennicy realistycznej interpretacji pojęcia rezonansu postulowali, aby uznawać struktury graniczne za odpowiedniki tautomerów, których nie można wyodrębnić metodami fizykalnymi i chemicznymi. Bardziej przekonującą interpretację struktur rezonansowych zaproponowano na gruncie teorii orbitali molekularnych. Zgodnie z nią, np. pojęciu rezonansu struktur granicznych cząsteczki benzenu odpowiada pojęcie sekstetu

27 Tak zwana 'sprawa Czelincewa' odnosi się do krytyki teorii rezonansu chemicznego w okresie stalinowskim w ZSRR. Twierdzono, że teoria rezonansu wyraża stanowisko idealizmu subiektywnego $\mathrm{i}$ jest niezgodna z doktryną materializmu dialektycznego. G. V. Czelincew był wpływowym chemikiem radzieckim, który inspirował ideologiczną krytykę teorii rezonansu chemicznego L. Paulinga. 
zdelokalizowanych elektronów $\pi$, który reprezentuje aromatyczność benzenu. Oba pojęcia są konstruktami teoretycznymi, których nie można interpretować realistycznie, lecz chemicy eksperymentatorzy traktują realistycznie rozkład ładunku elektronowego, który opisują odpowiednie molekularne funkcje falowe. Rozkład ładunku elektronowego w cząsteczce benzenu, opisywany w metodzie orbitali molekularnych, jest reprezentowany za pomocą wzoru strukturalnego, mającego postać sześciokąta foremnego, w który wpisany jest okrąg reprezentujący chmurę ładunku utworzoną przez zdelokalizowane elektrony $\pi$.

Dalsze losy ścierania dwóch filozoficznie odmiennych podejść do reprezentacji struktur cząsteczek związków chemicznych dowodzą, że przypisanie określonego statusu poznawczego tym reprezentacjom (formułom racjonalnym, wzorom strukturalnym) zależy od kontekstu teoretyczno-eksperymentalnego, w którym są one używane. $Z$ punktu widzenia laboratoryjnej praktyki badawczej w pełni racjonalne jest przypisywanie im statusu realistycznego, podczas gdy $\mathrm{w}$ analizach teoretycznych pełnią one jedynie rolę instrumentalnie traktowanych narzędzi o charakterze metaforycznym ${ }^{28}$.

\subsection{SPÓR O STATUS POZNAWCZY TEORII WIAZZAŃ CHEMICZNYCH}

Skoro przyjmuje się, że podstawowym przedmiotem zainteresowania chemii są właściwości molekuł, a zwłaszcza przemiany jakim one ulegają, to kluczowe pytanie, na które starali się odpowiedzieć chemicy teoretycy, brzmiało: co sprawia, że atomy łączą się ze sobą tworząc molekuły? Pierwszym, który udzielił odpowiedzi na to pytanie, przed ponad dwoma tysiącami lat zanim powstała chemia jako nowożytna

28 Zob. P. Zeidler P. Models and Metaphors as R esearch Tools in Science. A Philosophical, Methodological and Semiotic Study of Science, Zürich - Berlin 2013. Rolę wzorów strukturalnych w chemii organicznej analizował szczegółowo W. Goodwin., How do Structural Formulas Embody the Theory of Organic Chemistry, The British Journal for the Philosophy of Science 61(2010), 621-633. 
nauka przyrodnicza, był Demokryt ${ }^{29}$. Twierdził on, iż atomy mają haczyki, za pomocą których łączą się ze sobą. Jednakże koncepcja Demokryta, ze względu na wyłącznie spekulacyjny i zdroworozsądkowy charakter, nie miała wpływu na proces konstytuowania się naukowego pojęcia wiązania chemicznego, który został zapoczątkowany dopiero w drugiej połowie XIX wieku. Niepowodzeniem zakończyły się próby zastosowania mechaniki newtonowskiej, a zwłaszcza siły grawitacji, do wyjaśniania tendencji atomów do łączenia się w cząsteczki. Należy także odnotować, że ze względu na problemy związane $\mathrm{z}$ realistyczną interpretacją koncepcji atomistycznej $\mathrm{w}$ chemii pierwszej połowy XIX wieku, to sile powinowactwa chemicznego przypisywano odpowiedzialność za tworzenie się molekuł.

Pierwszą nowożytną teorią wiązania chemicznego była teoria wiązania polarnego, zgodnie $\mathrm{z}$ którą atomy (jony o przeciwnym ładunku) tworzą molekuły dzięki sile przyciągania elektrostatycznego. Koncepcja ta, zaproponowana przez Davy'ego a rozwinięta przez Berzeliusa na gruncie jego dualistycznej teorii budowy związków chemicznych, nie przypisywała wiązaniu chemicznemu statusu odrębnego bytu chemicznego. Jej zwolennicy twierdzili, że próby reifikacji wiązań chemicznych to 'metafizyczne bzdury'. Oczywistą konsekwencją powyższej koncepcji była redukcja właściwości chemicznych do właściwości fizycznych, co prowadziło do instrumentalistycznej interpretacji tych pierwszych. Słabością powyższego ujęcia wiązania było natomiast to, że nie tłumaczyło ono, dlaczego cząsteczki składające się $\mathrm{z}$ tych samych atomów, np. $\mathrm{O}_{2} \mathrm{lub} \mathrm{Cl}_{2}$, są trwałe, a także nie umożliwiało opisu połączeń atomów w związkach organicznych. Powyższe problemy rozwiązała dopiero elektronowa koncepcja wiązania kowalencyjnego (niepolarnego) Lewisa-Langmuira. Zgodnie $\mathrm{z}$ nią, wiązanie między atomami powstaje przez uwspólnienie elektronów pochodzących od łączących się atomów

29 Należy odnotować, że Demokryt nie posługiwał się pojęciem, które można by uznać za odpowiednik 'molekuły'. 
i jest utożsamiane z parą elektronów, która należy do obu atomów. Koncepcja ta reifikowała wiązanie chemiczne, traktując je realistycznie. Jej niewątpliwą zaletą było to, że umożliwiała prostą interpretację połączeń atomów w cząsteczkach i ich poglądową reprezentację za pomocą kresek, które stanowiły szkielet wzorów strukturalnych, a to z kolei umożliwiło budowanie poglądowych reprezentacji mechanizmów przemian chemicznych.

Jednakże z punktu widzenia kwantowo-mechanicznych koncepcji wiązania chemicznego, które powstały na bazie mechaniki falowej Schrödingera, wiązanie w ujęciu Lewisa-Langmuira było jedynie, dogodną z punktu widzenia praktyki eksperymentalnej chemii, metaforą. W latach trzydziestych XX wieku Linus Pauling ukonstytuował teorię wiązań kowalencyjnych, zgodnie z którą wiązania chemiczne są wyidealizowanymi i nieredukowalnymi konstrukcjami teoretycznymi. Teoria ta wpłynęła w istotny sposób na rozwój koncepcji struktury chemicznej i odniosła wiele eksplanacyjnych i predyktywnych sukcesów, zwłaszcza w zastosowaniu do analizy mechanizmów reakcji w chemii organicznej. Metoda wiązań walencyjnych opiera się na założeniu, że zakres stosowania funkcji falowych opisujących rozdzielone atomy może zostać rozszerzony na obszar molekularny. W tej metodzie funkcję falową zapisuje się dla każdej z możliwych struktur elektronowych cząsteczki. Sumaryczną funkcję otrzymuje się przez dodanie funkcji przypisanych poszczególnym strukturom kanonicznym wraz ze współczynnikami wagowymi. Reprezentują one graniczne rozmieszczenie elektronów w cząsteczce i mogą być interpretowane w świetle klasycznej teorii strukturalnej Lewisa. Jednakże koncepcja ta nie daje jednoznacznej podstawy do zdefiniowania pojęcia 'wiązanie chemiczne' na gruncie mechaniki falowej Schrödingera. Teoria ta umożliwia bowiem sformułowanie dwóch różnych definicji wiązania kowalencyjnego, a także można za jej pomocą konstruować funkcje falowe, które nie mają sensu empirycznego, lecz pozwalają obliczyć energię stanu podstawowego 
cząsteczki dobrze potwierdzoną przez eksperyment ${ }^{30}$. Powyższe fakty przemawiają na rzecz instrumentalnej interpretacji ujęcia wiązań chemicznych w metodzie wiązań walencyjnych.

Alternatywnej koncepcji wiązania chemicznego dostarczyła metoda orbitali molekularnych, zgodnie z którą cząsteczka rozpatrywana jest jako całość, dla której formułuje się równanie falowe Schrödingera. Orbital molekularny opisuje stan pojedynczego elektronu w cząsteczce, a kwadrat bezwzględnej wartości funkcji falowej (orbitalu molekularnego) może być interpretowany jako gęstość prawdopodobieństwa znalezienia elektronu, poruszającego się w polu wszystkich jąder tworzących cząsteczkę. Molekularne funkcje falowe (orbitale molekularne), podobnie jak atomowe funkcje falowe (orbitale atomowe), posiadają reprezentacje wizualne, które są niezwykle efektywnymi narzędziami badawczymi chemii laboratoryjnej, co powoduje, że bardzo silna jest wśród chemików eksperymentatorów tendencja do ich reifikacji. Jednakże orbitale molekularne, które stanowią matematyczną reprezentację wiązań chemicznych, zostały otrzymane dzięki przyjęciu kilku przybliżeń niezgodnych przynajmniej z niektórymi postulatami mechaniki kwantowej i dlatego, $z$ teoretycznego punktu widzenia, nie mogą być traktowane realistycznie ${ }^{31}$.

Alternatywną dla wcześniej omówionych teorii wiązania chemicznego była koncepcja energetyczna, która została zapoczątkowana przez Ostwalda i ściśle wiązała się z instrumentalistyczną interpretacją teorii atomistycznej ${ }^{32}$. $Z$ jej perspektywy ważne jest ustalenie

30 Podstawowe informacje dotyczące teorii wiązań walencyjnych i teorii orbitali molekularnych można znaleźć np. w: W. Kołos, Chemia kwantowa, Warszawa 1975 lub W. Kołos, J. Sadlej, Atom i czq̨steczka, Warszawa 2007.

31 Powyższe zagadnienie omówiłem szczegółowo w dwóch artykułach: P. Zeidler, Spór o status ontologiczny orbitali atomowych i molekularnych w kontekście zagadnienia autonomii chemii w: tenże, dz. cyt. 109-118 oraz Czy można zaobserwować orbitale? O problemie obserwowalności i realności przedmiotów teoretycznych w: tamże 119-135.

32 Zob. na ten temat R.F. Hendry, The Chemical Bond, w: Philosophy of Chemistry. Handbook of the Philosophy of Science - Volume 6, red. A.I. Woody, R.F. Hendry, P. Needham, Amsterdam-Oxford, 2012, 305-306. 
energii utrzymującej cząsteczkę w całości, a nie analiza wiązania chemicznego, któremu nie przypisuje się statusu odrębnego bytu chemicznego. Badanie siły wiążącej poszczególne części składowe cząsteczki jest dokonywane na gruncie termodynamiki przez odwołanie się do prawa Hessa, które umożliwia obliczenie siły wiązania jako różnicę między ciepłem tworzenia a ciepłem rozpadu danego połączenia jej elementów. Energetyczna koncepcja wiązania nie może jednakże pełnić wielu istotnych funkcji, jakie pełnią klasyczne lub kwantowo-mechaniczne teorie wiązania chemicznego, które zasadzają się na jego uprzedmiotowieniu. Tym samym posiada ona niewielkie znaczenie, na przykład dla praktyki laboratoryjnej chemii organicznej, w której wyjaśnienie przebiegu reakcji, a więc zaproponowanie jej mechanizmu, wykorzystuje takie pojęcia jakościowe, jak np. przesunięcie ładunku w obrębie cząsteczki, rozerwanie wiązania, utworzenie wiązania i szereg innych. $Z$ teoretycznego punktu widzenia wymienione pojęcia stanowią jedynie metaforyczne narzędzia, za pomocą których konstruujemy hipotezy wyjaśniające przebieg przemian chemicznych, lecz chemicy eksperymentatorzy mają tendencję do ich realistycznego interpretowania, gdyż to wpływa na efektywność ich praktyki laboratoryjnej, która ze swej natury jest substancjalistyczna. Można zatem przyjąć, że energetyczna koncepcja wiązania stanowi bardzo istotne, lecz w pewnym sensie pomocnicze narzędzie termodynamicznej charakterystyki przebiegu przemian chemicznych. W przypadku pojęcia 'wiązania chemicznego' mamy więc do czynienia $z$ instrumentalistycznym profilem epistemologicznym przypisywanym temu pojęciu przez chemików teoretyków i tendencją do jego realistycznego interpretowania przez chemików pracujących w laboratoriach.

\section{ZAKOŃCZENIE}

W pełni przekonujące uzasadnienie tezy, iż rozwój aparatu pojęciowego chemii był ściśle związany ze ścieraniem się różnych profili 
epistemologicznych podstawowych pojęć chemii, wymagałoby szczególowych studiów z zakresu historii chemii. Jednakże nawet powyższe skrótowe rozważania wykazują, że kształtowaniu się aparatu pojęciowego chemii w XIX wieku i na początku wieku XX towarzyszyło stałe napięcie zachodzące pomiędzy instrumentalistyczną interpretacją konstruktów teoretycznych a realistycznym nastawieniem chemików pracujących w laboratoriach. Profile epistemologiczne pojęć chemicznych były uzależnione od celów, jakie za ich pomocą miały być realizowane w praktyce badawczej chemii. Stosunek do rzeczywistości, do badania której konstrukcje te były tworzone, był określany w zależności od sposobu ich wykorzystania w praktyce badawczej chemii. Twórcy podstaw teoretycznych chemii byli skłonni rozpatrywać swoje konstrukty pojęciowe jako narzędzia praktyki teoretyczno-eksperymentalnej chemii i traktować je instrumentalnie. Natomiast eksperymentatorzy, mając świadomość instrumentalnego statusu poznawczego wielu stosowanych przez siebie konstrukcji teoretycznych, dokonywali ich reifikacji, gdyż dzięki temu stawały się one efektywnym narzędziem praktyki eksperymentalnej. Ze ścierania się tych dwóch przeciwstawnych postaw epistemologicznych doszło do powstania stanowiska racjonalizmu stosowanego, które charakteryzuje praktykę eksperymentalną współczesnej chemii.

\section{BIBLIOGRAFIA}

Bachelard G., Filozofia, która mówi nie. Esej o filozofii nowego ducha w nauce, thum. z fr. J. Budzyk, Wydawnictwo słowo/obraz terytoria, Gdańsk 2000.

Bantz D., The Structure of Discovery: Evolution of Structural Accounts of Chemical Bonding, w: Scientific Discovery: Case Studies, red. T. Nickles, Reidel Publishing Company, Dordrecht-Boston-London 1980, 291-329.

Bensaude-Vincent B., Chemistry Beyond the 'Positivism vs Realism' Debate, w: Stuff. The Nature of Chemical Substances, red. K. Ruthenberg, J. van Brakel, Königdhausen \& Neumann, Würzburg 2008, 45-53.

Bensaude-Vincent B., Simon J., Chemistry the Impure Science, Imperial College Press, London, 2008. 
Brock W.H., Historia chemii, tłum. z ang. J. Kuryłowicz, Pruszyński i S-ka, Warszawa 1999.

Butlerow A.M., Teoria budowy zwiqzków organicznych. Wybór pism, PWN, Warszawa 1953.

Feyerabend P., Realizm i instrumentalizm. Uwagi o logice potwierdzania przez fakty, w: tenże, Jak być dobrym empirysta, tłum. z ang. K. Zamiara, Warszawa 1979, 152-193.

Goodwin W., How do Structural Formulas Embody the Theory of Organic Chemistry, The British Journal for the Philosophy of Science 61(2010), 621-633.

Hendry R.F., The Chemical Bond, w: Philosophy of Chemistry. Handbook of the Philosophy of Science - Volume 6, red. A.I. Woody, R.F. Hendry, P. Needham, Elsevier, Amsterdam-Oxford, 2012, 293-307.

Kołos W., Chemia kwantowa, PWN, Warszawa 1975.

Kołos W., Sadlej J., Atom i czasteczka, Wydawnictwa Naukowo-Techniczne, Warszawa 2007.

Leszczyński D., Ciagtośc i zerwanie w historii wiedzy, Semper, Warszawa 2008.

Leszczyński D., Szlachcic K., Wprowadzenie do francuskiej filozofii nauki. Od Comte'a do Foucaulta, Wydawnictwo Uniwersytetu Wrocławskiego, Wrocław 2003.

Mierzecki R., Historyczny rozwoój pojęć chemicznych, PWN, Warszawa 1985.

Synowiecki A., Tendencje mechanistyczne w rozwoju chemii nowożytnej, w: $Z$ dziejów mechanicyzmu w fizyce i chemii, red. W. Krajewski, Zakład Narodowy im. Ossolińskich, Wydawnictwo PAN, Wrocław-Warszawa-Kraków-Gdańsk 1974, 91-143.

van Brakel J. , Philosophy of Chemistry. Between the Manifest and the Scientific Image, Leuven University Press, Leuven 2000.

Zeidler P., Chemia w świetle filozofi. Studia z flozofi, metodologii i semiotyki chemii, Wydawnictwo Naukowe IF UAM, Poznań 2011.

Zeidler P., Czy można zaobserwować orbitale? O problemie obserwowalności $i$ realności przedmiotów teoretycznych, w: tenże, Chemia w świetle filozofii. Studia z flozofi, metodologii i semiotyki chemii, Wydawnictwo Naukowe IF UAM, Poznań 2011, 119-135.

Zeidler P., Models and Metaphors as Research Tools in Science. A Philosophical, Methodological and Semiotic Study of Science, LIT Verlag, Zürich - Berlin 2013.

Zeidler P., O pokonywaniu przeszkody substancjalistycznej w chemii w świetle stanowiska racjonalizmu stosowanego Gastona Bachelarda, w: Granice nauki, red. Z. Pietrzak, Lectiones\&Acroases Philosophicae 6(2013)1, 33-57. 
Zeidler P., Semiotyczny i poznawczy status wzorów strukturalnych zwiq̨zków chemicznych a przyczynowa teoria oznaczania, w: tenże, Chemia w świetle filozofii. Studia z flozofi, metodologii $i$ semiotyki chemii, Wydawnictwo Naukowe IF UAM, Poznań 2011, 137-152.

Zeidler P., Spór o status ontologiczny orbitali atomowych i molekularnych w kontekście zagadnienia autonomii chemii, w: tenże, Chemia w świetle filozofi. Studia z filozofi, metodologii $i$ semiotyki chemii, Wydawnictwo Naukowe IF UAM, Poznań 2011, 109-118.

\section{PHILOSOPHICAL ASPECTS OF THE FORMATION OF THE CONCEPTUAL APPARATUS OF CHEMISTRY}

Abstract. There is a widespread belief among philosophers of science that the dispute about
realism does not significantly affect the practice of natural sciences, and that a realistic
attitude is a common epistemological position adopted by naturalists. In this paper an
argument is brought forward to support the thesis that theoretical concepts formulated in
the natural sciences evoke significant cognitive controversies among scientists, having an
impact on their scientific practices. Gaston Bachelard's thesis will be considered, according
to which the realistic 'load' of the conceptual apparatus in any given science has a significant
impact on its development. The investigation conducted in this paper will be based on the
analysis of examples taken from the research practice of nineteenth century and early
twentieth century chemistry. The problem to be discussed here deals with the cognitive
status of beliefs about the existence of the referents of such concepts as: atom (chemical
atom), structural formula (rational formula) and chemical bond.

Keywords: dispute about realism, Gaston Bachelard, conceptual apparatus, chemical atom, structural formula, chemical bond

PAWEL ZEIDLER

zeidlerp@amu.edu.pl

Uniwersytet im. Adama Mickiewicza w Poznaniu, Instytut Filozofii

Szamarzewskiego 89c, 60-569 Poznań

DOI: 10.21697/spch.2016.52.4.17 